\title{
Evidence of Euryhalinity of the Gulf Corvina (Cynoscion othonopterus)
}

\author{
M. PEREZ-VELAZQUEZ ${ }^{1}$, P. URQUIDEZ-BEJARANO ${ }^{1}$, M. L. GONZÁLEZ-FÉLIX ${ }^{1}$, \\ C. MINJAREZ-OSORIO ${ }^{1}$
}

${ }^{1}$ Department of Scientific and Technological Research, University of Sonora, Hermosillo, Sonora, Mexico

Received September 6, 2013

Accepted February 28, 2014

On-line June 5, 2014

\begin{abstract}
Summary
The effects of environmental salinity on physiological responses, growth, and survival of the Gulf corvina, C. othonopterus, were evaluated in a 6-week completely randomized design experiment. Corvina (17.2 $\pm 2.3 \mathrm{~g}$ mean initial body weight) were subjected to salinities of 5, 15, 25, and $35 \%$ and fed a commercial feed with protein and lipid contents of 46 and $14 \%$, respectively. Plasma osmolality increased significantly with salinity, ranging from $335.1 \pm 5.3 \mathrm{mOsm} / \mathrm{kg}$ in fish maintained at $5 \%$, to $354.8 \pm 6.8$ $\mathrm{mOsm} / \mathrm{kg}$ in fish kept in seawater, while a significant inverse relationship was observed between salinity and moisture content of whole fish, ranging from $73.8 \pm 0.7$ (measured at $5 \%$ ) to $76.9 \pm 1.0 \%$ (measured at $35 \%$ ). In spite of this, growth indices (final weight, weight gain, specific growth rate, condition factor, survival) were not altered, suggesting that, like other members of the family Sciaenidae, the Gulf corvina is a strong osmoregulator. The isosmotic point for this species was estimated to correspond to a salinity of $9.8 \%$. The present study represents the first set of experimental data on salinity tolerance of $C$. othonopterus and confirms the euryhalinity of this species.
\end{abstract}

\section{Key words}

Salinity • Osmolality • Euryhaline • Cynoscion othonopterus

\section{Corresponding author}

M. Perez-Velazquez, Departamento de Investigaciones Científicas y Tecnológicas, Universidad de Sonora, Edificio 7-G, Blvd. Luis Donaldo Colosio s/n, e/Sahuaripa y Reforma, Col. Centro, C.P. 83000, Hermosillo, Sonora, México. Fax: +52-662-259-2197. E-mail: mperezv@dictus.uson.mx
The recent near-collapse of the shrimp farming industry in Northwest Mexico, to a large extent caused by shrimp diseases (Rosales-Leija et al. 2012), has catapulted the interest in the production of marine fish. The Gulf corvina, Cynoscion othonopterus, a member of the family Sciaenidae native to northwest Mexico that is highly appreciated for its top-quality meat and that supports a commercial fishery of over 3,000 MT (Ministry of Agriculture, Livestock, Rural Development, Fisheries, and Food 2012), is currently being evaluated as a candidate for aquaculture in Sonora, Mexico. Reproduction in captivity and growout in sea-cages is currently being explored as an alternative to shrimp culture. In general, fish belonging to the family Sciaenidae, such as the spotted sea trout, Cynoscion nebulosus (Cuvier), and the shi drum, Umbrina cirrosa (Linnaeus, 1758), are considered euryhaline species, i.e., capable of tolerating a wide range of environmental salinities (Miranda and Sonski 1985, Kucera et al. 2002, Doroudi et al. 2006, Mylonas et al. 2009). For aquacultural purposes, this feature may be advantageous for the diversification of finfish production in low salinity waters, which have a different ionic profile compared to natural seawater. Interestingly, for some marine fish species, growth and/or survival are compromised when reared below full-strength seawater salinity (Sampaio and Bianchini 2002), while the opposite has been observed for others (Imsland et al. 2008). As a member of the Sciaenidae family, the Gulf corvina is also thought to be a euryhaline species, for it displays a reproductive seasonal migration to the Colorado River Delta in the northern portion of the Gulf of California, where it encounters 
lower environmental salinities and spawns (Rowell et al. 2005, Encinas-Rivera 2008). However, no experimental studies of the growth response and tolerance of this species to a wide range of environmental salinities are available in the literature. In the present study, the effects of environmental salinity on physiological responses, growth, and survival of $C$. othonopterus were investigated.

Juvenile $C$. othonopterus of the same cohort, originating from wild spawners and reared in full-strength seawater, were obtained from the "Centro Reproductor de Especies Marinas del Estado de Sonora" at Kino Bay, Sonora, Mexico. Fish were transported to the Wet Laboratory of Aquaculture Nutrition of the Kino Bay Experiment Station (KBES), University of Sonora at Kino Bay, Sonora, Mexico. Fish were stocked into a $10 \mathrm{~m}^{3}$ fiberglass raceway. Because in its natural habitat the Gulf corvina feeds mainly on sardine (Cetengraulis mysticetus) (Román-Rodríguez 2000), fish were fed a commercial fish feed for seawater carnivorous fish (Nutripec, Agribrands Purina, Jalisco, México), with dietary protein and lipid contents of 46 and $14 \%$, respectively. After one week and with an overall mean weight ( \pm standard deviation, SD) of $17.2 \pm 2.3 \mathrm{~g}$, fish were transferred into experimental tanks for initiation of the study.

The study was conducted in polyethylene, circular tanks (71 cm diameter, $0.4 \mathrm{~m}^{2}$ bottom area), filled with 2001 of water. Each tank was provided with a submerged airstone for water aeration supplied by a 1.0HP blower (Fuji, Model VFC40, Saddle Brook, New Jersey, USA). Salinities of 5, 15, 25, and $35 \%$ were tested in a completely randomized design experiment. Each experimental treatment was assigned to three replicate tanks. Fish were stocked into tanks at a rate of 6 individuals per tank ( 30 fish per $\mathrm{m}^{3}$ ). For acclimation, salinity was lowered at a rate of $1 \% / \mathrm{h}$ by gradually adding freshwater to the experimental tanks using irrigation button drip emitters (Submatic Irrigation Systems, Model BE 1/2-10, Austin, Texas, USA). Once acclimation of all treatments was achieved, fish were maintained in the tanks for six weeks.

All fish were fed the commercial feed described earlier to moderate excess, dividing the daily ration into three equal portions, administered at 09:00, 14:00, and 19:00 h. Uneaten feed and feces were siphoned out of the tanks daily. In order to keep water clean throughout the experiment, a daily water exchange of $50 \%$ was applied using water previously adjusted for salinity and aerated for $24 \mathrm{~h}$. Daily measurements of water temperature, dissolved oxygen, and salinity were taken with a multifunction oxygen meter (YSI, Model Y85, Yellow Springs, OH, USA). Weekly, $\mathrm{pH}$ was measured with a handheld $\mathrm{pH}$ meter (Oakton ${ }^{\circledR}$, model Double Junction pHTestr 1, Vernon Hills, Illinois, USA).

At the end of the experiment, a freezing-point technology osmometer (Advanced Instruments, Inc., Model 3320, Norwood, Massachusetts, USA) was employed to evaluate the osmolality (reported as $\mathrm{mOsm} / \mathrm{kg}$ ) of experimental waters and plasma of all fish. Following the Mexican technical specifications for the production, care and use of experimental animals (Official Mexican Norm 2001), fish were anesthetized with MS222 before caudal severance. Then, approximately $1 \mathrm{ml}$ of blood was withdrawn from the caudal blood vessel of each fish with a 25 -gauge needle and 1-cc syringe, and placed into a 1.7-ml micro centrifuge tube (Costar Corning Incorporated, $1.7 \mathrm{~mL}$ Corning, NY, USA) kept on ice. Fish were then sacrificed by severing of the spinal cord and frozen for further analysis. Blood samples were centrifuged at $850 \mathrm{xg}$ for $15 \mathrm{~min}$ to separate cells from plasma. Total osmolality was then measured using $20 \mu \mathrm{l}$ of plasma. Both plasma and experimental water samples were analyzed in duplicate. Plasma and culture water osmolality data were both regressed against salinity. The intersection between the two regression lines estimated the isosmotic point.

Duplicate composite samples (of $8 \mathrm{~g}$ each) of three whole fish from each of three experimental tanks, were taken to determine moisture (Method 930.15) and ash (Method 942.05) content, following the procedures of the Association of Official Analytical Chemists (2005).

Length $(\mathrm{mm})$ and weight $(\mathrm{g})$ of fish were individually measured at the beginning and end of the study. Weight gain was calculated from the difference between final minus initial weight. Survival rate was calculated from the difference between final and initial numbers of fish per tank: (final number of fish $\mathrm{x}$ 100)/initial number of fish). The Fulton's condition factor (K) (Ricker 1975), a measurement of the robustness of fish, was calculated as $\mathrm{K}=\left[\left(\right.\right.$ weight $\left.\left._{\text {length }}{ }^{3}\right)\right] \mathrm{x} 100$. In addition, the specific growth rate (SGR) was calculated as $\mathrm{SGR}=[\ln$ (final weight - initial weight) $][100] /$ time (days).

Using a significance level of $P \leq 0.05$, one-way analysis of variance (ANOVA) was employed to evaluate treatment differences in fish performance (growth indices, survival, K, FCR, and SGR), plasma osmolality, 
moisture, and ash content of whole fish, while Repeated Measures ANOVA was employed to analyze water quality data (dissolved oxygen, temperature, and $\mathrm{pH}$ ). Differences among treatments were identified by Duncan's method. Percent survival rates were arcsinetransformed prior to statistical analysis; untransformed values are presented. Data analyses were performed using Statistical Analysis System software (SAS Institute, Inc. 1989-95).

The measurements (treatment means \pm SD) of temperature at the salinity treatments $5,15,25$, and $35 \%$ were $25.9 \pm 2.0,25.7 \pm 1.9,26.5 \pm 2.0$, and $26.7 \pm 2.1^{\circ} \mathrm{C}$, respectively. For dissolved oxygen, they were $7.1 \pm 0.4$, $7.0 \pm 0.4,6.7 \pm 0.4$, and $6.7 \pm 0.4 \mathrm{mg} / \mathrm{l}$, respectively, while for $\mathrm{pH}$, they were $7.5 \pm 0.1,7.5 \pm 0.1,7.7 \pm 0.1$, and $7.7 \pm 0.1$, respectively. These parameters are within the range of values either observed in the natural habitat of this species, or employed in studies in which satisfactory growth and survival of other fishes belonging to the same family has been recorded (Neill 1990, Rowell et al. 2005, Martínez-Llorens et al. 2011, Minjarez-Osorio et al. 2012). Hence, it is considered that adequate overall water quality was maintained throughout this study.

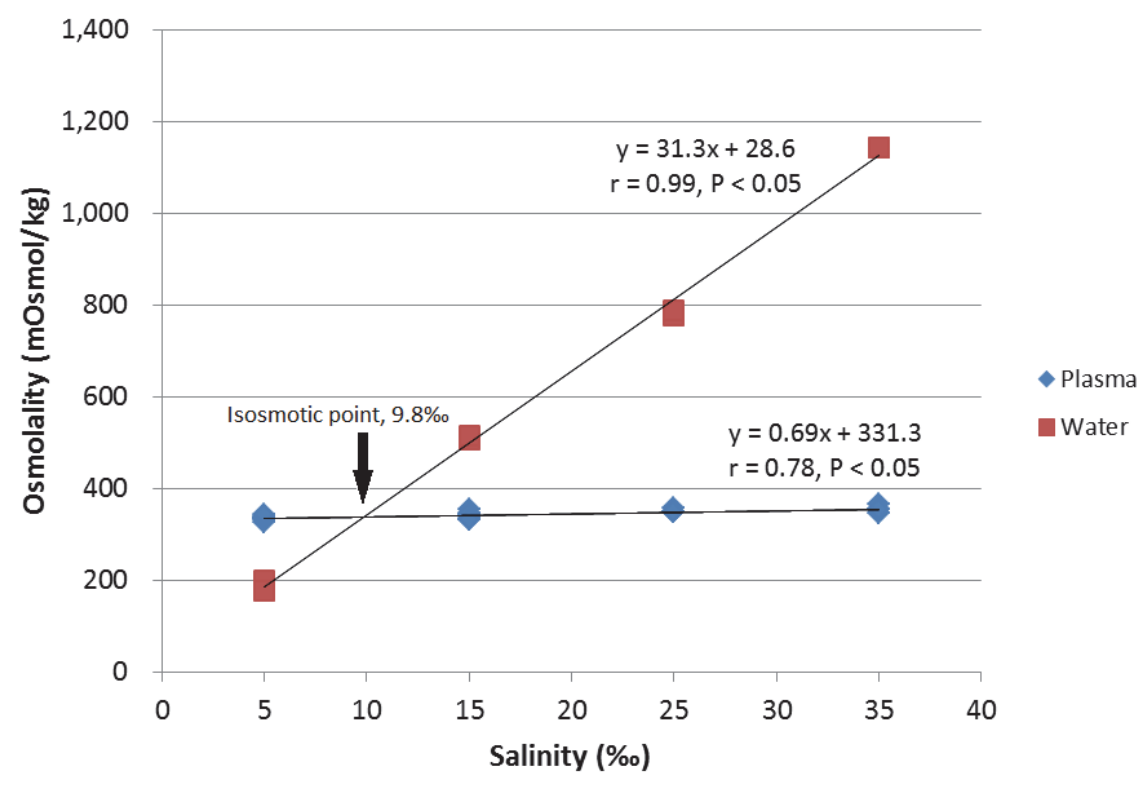

Fig. 1. Regression lines between salinity and culture water or plasma osmolality of $C$. othonopterus reared at different salinities. The point of intersection between the lines represents the estimated isosmotic point $(9.8 \%$ ).

Mean plasma osmolality, which varied from $335.1 \pm 5.3 \mathrm{mOsm} / \mathrm{kg}$ in fish maintained at $5 \%$, to $354.8 \pm 6.8 \mathrm{mOsm} / \mathrm{kg}$ in fish kept in seawater, lies within the range of values generally observed in marine fish (335-480 mOsm/kg) (Jobling 1995, Sampaio and Bianchini 2002, Resley et al. 2006), and it is notably similar to values found in other members of the Sciaenidae family like the red drum, Sciaenops ocellatus (350 $\mathrm{mOsm} / \mathrm{kg}$, measured in seawater) (Crocker et al. 1983), the shi drum, U. cirrosa (350-409 $\mathrm{mOsm} / \mathrm{kg}$, measured in $40 \%$ water) (Mylonas et al. 2009), and the dusky kob, Argyrosomus japonicus (362 mOsm/kg, measured in $35 \%$ water) (Bernatzeder et al. 2008). In the present study, the differences detected in the plasma osmolality values, significantly lower for fish kept at 5 and $15 \%$, with respect to fish at 25 and $35 \%$, along with the significantly higher moisture contents observed as salinity decreased, suggest some degree of physiological stress imposed by the low salinity.
However, from the very small slope found for the linear relationship between salinity and plasma osmolality ( $0.69 \mathrm{mOsm} / \mathrm{kg} / \%$, Fig. 1) and the fact that none of the growth responses measured, survival, or the ash content of whole fish were statistically affected by the salinities imposed (Table 1), it seems evident that fish were able to adapt satisfactorily to low salinity. These results represent the first set of experimental data on the salinity tolerance of $C$. othonopterus and confirm the euryhaline nature of this species. Relative constancy of plasma osmolality, with little or no effects on growth in response to salinity, has also been observed in other euryhaline teleosts. For example, plasma osmolality of the rabbitfish (Siganus rivulatus) varied from 398 to $435 \mathrm{mOsm} / \mathrm{kg}$ after being exposed for 3 weeks to salinities ranging from 10 to $50 \%$, while growth of this highly euryhaline species was only slightly affected (Saoud et al. 2007). Similarly, Resley et al. (2006) reported that over the salinity range of 5 to $35 \%$, plasma osmolality of juvenile cobia varied 


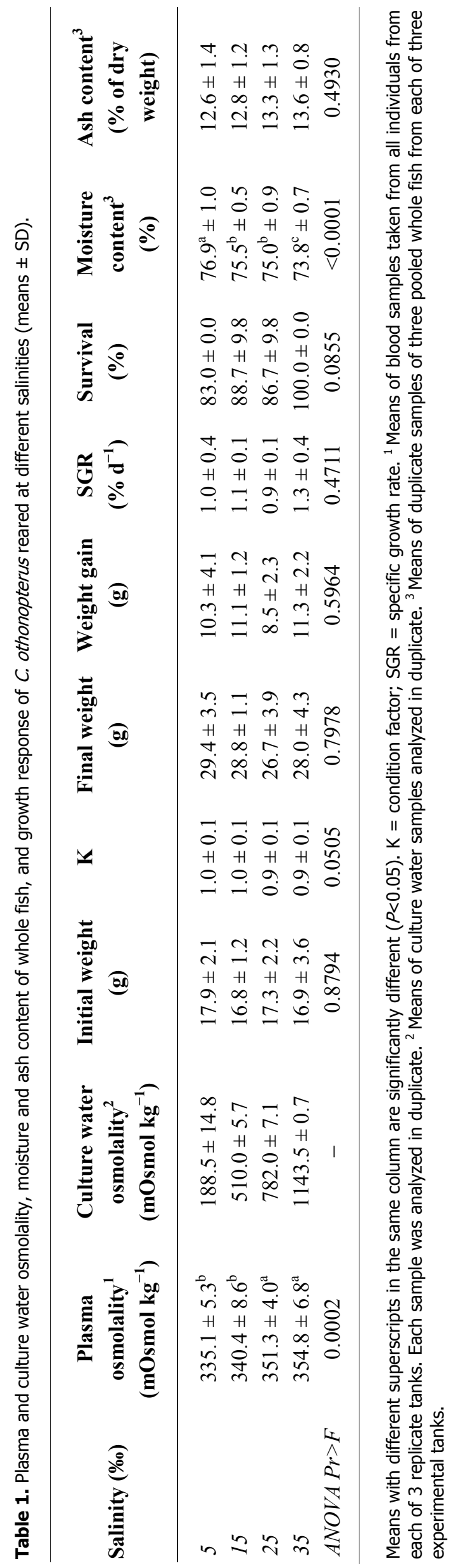


from 318.8 to $335.5 \mathrm{mmol} / \mathrm{kg}$, but growth performance of fish was not influenced. Furthermore, findings of the present study agree with the overall range of salinity tolerance, from 5 to $45 \%$, found for sciaenids such as $S$. ocellatus, U. cirrosa, A. regius, A. japonicus, and $A$. inodorus (Wurts and Stickney 1993, Fielder and Bardsley 1999, Tomasso and Kempton 2000, Doroudi et al. 2006, Ferreira et al. 2008, Partridge et al. 2008, Mylonas et al. 2009, Partridge and Lymbery 2009, Márquez et al. 2010). Other teleost fish also considered as strong osmorregulators include the widely studied salmonids (Varsamos et al. 2005), as well as some flatfish (Sampaio and Bianchini 2002, Imsland et al. 2008), some groupers (Tsui et al. 2012, Cheng et al. 2013), and some cyprinids (Kolbadinezhad et al. 2012), among others. Conversely, stenohaline species, unable to adapt to large variations in salinity, display wider changes in plasma osmolality often accompanied by acute or lethal effects when subjected to salinity challenge. For instance, baseline plasma osmolality of the sunshine bass (hybrid of white bass Morone chrysops $q \times$ striped bass $M$. saxatilis ${ }^{\text {T) }}$ ) and the palmetto bass (striped bass $q \times$ white bass $\delta$ ) (360 and $351 \mathrm{mmol} / \mathrm{kg}$, respectively), increased to 415 and 530 $\mathrm{mmol} / \mathrm{kg}$, respectively, after a 24 -h stepwise elevation in salinity from 1 to $52 \%$. Both species were unable to survive at high salinity (Myers and Kohler 2000). Similar responses have been observed in other fresh and marine fish exposed to high or low salinity, respectively (Bystriansky et al. 2007, Suchy 2007). The findings of the present study, conducted for 6 weeks within the salinity range of 5-35\%, support further investigation of the osmoregulatory capacity of the Gulf corvina. For example, long-term exposure to a further extended low salinity range should be examined. Taking into account that the survival rates observed at salinities below fullstrength seawater $(83.0-88.7 \%)$ were numerically, but not statistically, lower than that observed in seawater $(100.0 \%)$, this approach would help elucidate the effects of long-term exposure to low salinity on this and other response variables. Different sizes of fish, including larvae, juveniles, subadults, and adults could also be included, taking into account that salinity has been shown to vary with size/age for certain species (Rajabi and Khodabandeh 2013).

Osmolality of culture water also increased directly with salinity. Significant $(P<0.05)$ positive linear relationships were found between salinity and both culture water $(\mathrm{r}=0.99)$ and plasma osmolality $(\mathrm{r}=0.78)$. The isosmotic point for $C$. othonopterus, i.e., the point of intersection between these lines, was estimated to be $9.8 \%$ o (Fig. 1), which is comparable to the that of the flounder Paralichthys orbignyanus (10.9\%o) (Sampaio and Bianchini 2002), another euryhaline marine fish.

The osmoregulatory capacity of the Gulf corvina observed in the present study is consistent with changes in salinity that this species successfully faces along its annual reproductive migration (Rowell et al. 2005, Encinas-Rivera 2008). In fact, it appears that $C$. othonopterus not only withstands lower salinities down to $26 \%$ in the Colorado River Delta, but requires these estuarine conditions for successful spawning and nursing (Rowell et al. 2005). As a consequence of the construction of upstream dams that stopped the flow of the Colorado River into the Gulf of California, capture fisheries of the Gulf corvina completely disappeared in the 1960s (Román-Rodriguez 1998). After controlled pulses of Colorado River water were released into the Gulf of California in the early 1990s, commercial fishery of this species re-emerged (Román-Rodriguez 2000, Rowell et al. 2005, Encinas-Rivera 2008). The mechanisms of osmotic regulation of euryhaline marine fish, which include high drinking rates of sea water, active uptake of ions along the digestive tract, coupled with osmotic intake of water, have been comprehensively studied and reviewed by various authors (Evans 1999, Wilson and Laurent 2002, Hirose et al. 2003, Versamos et al. 2005). It would be of interest to examine these physiological aspects in future studies of Gulf corvina.

With respect to the magnitude of growth of the Gulf corvina observed in the present study, the mean SGR values, which varied from 0.9 to $1.3 \%$, are at the lower end of the range of SGR values (fluctuating from 0.7 to approximately $4 \% / \mathrm{d}$ ) documented for a variety of species and sizes of sciaenids, such as A. japonicus, $S$. ocellatus, Pseudosciena crocea, Nibea michthioides, and Totoaba macdonaldi (Jirsa et al. 1997, McGoogan and Gatlin 1999, Duan et al. 2001, Turano et al. 2002, Wang et al. 2006, Pirozzi et al. 2010, Minjarez-Osorio et al. 2012). However, it is worth pointing out that the present study was conducted in indoor tanks with limited space, and that important aspects such as the nutritional requirements for optimum growth of this species are still unknown. It is expected that, once these requirements are fulfilled, greater growth rates can be obtained for this species, especially when reared in adequate infrastructure for commercial culture, e.g., floating or submersible cages. The estimated mean values of the condition factor for the Gulf corvina varied from 0.9 to 1.0 (Table 1), and 
were very similar to estimates of other members of the Sciaenidae family like Micropogonias furnieri (ranging from approximately 1.0 to 1.2 ) (Manickchand-Heileman and Kenny 1990), and T. macdonaldi (reported mean value of 1.1) (Minjarez Osorio et al. 2012).

In conclusion, plasma osmolality and whole body moisture content of the Gulf corvina, $C$. othonopterus, were statistically influenced after being reared for 6 weeks within the salinity range of 5 to $35 \%$. However, none of the growth responses, as evaluated by final weight, weight gain, specific growth rate, condition factor, or survival of fish were affected, indicating that the Gulf corvina is a strong osmoregulator. The present study represents the first set of experimental data on salinity tolerance of $C$. othonopterus and confirms the euryhalinity of this species.

\section{Conflict of Interest}

There is no conflict of interest.

\section{Acknowledgements}

This research was supported by the "Fondo Sectorial SAGARPA" of the National Council for Research and Technology (CONACYT), Mexico, under Grant 201108-164673. Perla Urquidez-Bejarano and Christian Minjarez-Osorio are both graduate students at the University of Sonora, sponsored by CONACYT, Mexico.

\section{References}

ASSOCIATION OF OFFICIAL ANALYTICAL CHEMISTS: Official Methods of Analysis. Association of Analytical Chemists, Arlington, VA, USA, 2005.

BERNATZEDER AK, COWLEY PD, HECHT T: Effect of short term exposure to the anaesthetic 2-phenoxyethanol on plasma osmolality of juvenile dusky kob, Argyrosomus japonicus (Sciaenidae). J Appl Ichthyol 24: 303-305, 2008.

BYSTRIANSKY JS, FRICK NT, RICHARDS JG, SCHULTE PM, BALLANTYNE JS: Failure to up-regulate gill $\mathrm{Na}^{+}, \mathrm{K}^{+}$-ATPase $\alpha$-subunit isoform $\alpha \mathrm{lb}$ may limit seawater tolerance of land-locked Arctic char (Salvelinus alpinus). Comp Biochem Physiol Part A 148: 332-338, 2007.

CHENG SY, CHEN CS, CHEN JC: Salinity and temperature tolerance of brown-marbled grouper Epinephelus fuscoguttatus. Fish Physiol Biochem 39: 277-286, 2013.

CROCKER PA, ARNOLD CR, DEBOER JA, HOLT GJ: Blood osmolality shift in juvenile red drum, Sciaenops ocellatus L. exposed to fresh water. J Fish Biol 23: 315-319, 1983.

DOROUDI MS, FIELDER DS, ALLAN GL, WEBSTER GK: Combined effects of salinity and potassium concentration on juvenile mulloway (Argyrosomus japonicus, Temminck and Schlegel) in inland saline groundwater. Aquacult Res 37: 1034-1039, 2006.

DUAN Q, MAI K, ZHONG H, SI L, WANG X: Studies on the nutrition of the large yellow croaker, Pseudosciaena crocea R. I: growth response to graded levels of dietary protein and lipid. Aquacult Res 32 (Suppl 1): 46-52, 2001.

ENCINAS-RIVERA YM: Analysis of Stomach Contents of Cynoscion othonopterus (Jordan and Gilbert) in the Upper Gulf of California and Colorado River Delta. B.S. Biology Thesis. (in Spanish) Technological Institute of Yaqui Valley, Bacum, Sonora, Mexico, 2008, 52 pp.

EVANS DH: Ionic transport in the fish gill epithelium. J Exp Zool 283: 641-652, 1999.

FERREIRA HL, VINE NG, GRIFFITHS CL, KAISER H: Effects of salinity on growth juvenile silver kob, Argyrosomus inodorus (Teleostei: Scieanidae). Af J Aqua Sci 33: 161-165, 2008.

FIELDER DS, BARDSLEY W: A preliminary study on the effects of salinity on growth and survival of mulloway Argyrosomus japonicus larvae and juveniles. J World Aquacult Soc 30: 380-387, 1999.

HIROSE S, KANEKO T, NAITO N, TAKEI Y: Molecular biology of major components of chloride cells. Comp Biochem Physiol, Part B 136: 593-620, 2003.

IMSLAND AK, GÚSTAVSSON A, GUNNARSSON S, FOSS A, ÁRNASON J, ARNARSON I, JÓNSSON AF, SMÁRADÓTTIR H, THORARENSEN H: Effects of reduced salinities on growth, feed conversion efficiency and blood physiology of juvenile Atlantic halibut (Hippoglossus hippoglossus L.). Aquaculture 174: 254-259, 2008. 
JIRSA DO, DAVIS DA, ARNOLD CR: Effects of dietary nutrient density on water quality and growth of red drum Sciaenops ocellatus in closed systems. J World Aquacult Soc 28: 68-78, 1997.

JOBLING M: Environmental Biology of Fishes. Chapman \& Hall, London, 1995, 455 pp.

KOLBADINEZHAD SM, HAJIMORADLOO A, GHORBANI R, JOSHAGHANI H, WILSON JM: Effects of gradual salinity increase on osmoregulation in Caspian roach Rutilus caspicus. J Fish Biol 81: 125-134, 2012.

KUCERA CJ, FAULK CK, HOLT GJ: The effect of parental acclimation to spawning salinity on the survival of larval Cynoscion nebulosus. J Fish Biol 61: 726-738, 2002.

MANICKCHAND-HEILEMAN SC, KENNY JS: Reproduction, age, and growth of the whitemouth croaker Micropogonias furnieri (Desmarest 1823) in Trinidad waters. Fish Bull 88: 523-529, 1990.

MÁRQUEZ P, TINOCO AB, RUIZ-JARABO I, VARGAS-CHACOFF L, RODRÍGUEZ-RÚA A, CÁRDENAS S, MANCERA JM: Osmoregulatory and metabolic responses of fry and juvenile meagre (Argyrosomus regius) to different environmental salinities. 9th International Congress on the Biology of Fish, 5 to 9 July 2010, Universidad Autónoma de Barcelona, Spain, 2010.

MCGOOGAN BB, GATLIN DM: Dietary manipulations affecting growth and nitrogenous waste production of red drum Sciaenops ocellatus I. Effects of dietary protein and energy levels. Aquaculture 178: 333-348, 1999.

MINISTRY OF AGRICULTURE, LIVESTOCK, RURAL DEVELOPMENT, FISHERIES, AND FOOD: National Fisheries Chart. (in Spanish) Official Journal of the Federation, August 24, 2012, Mexico.

MINJAREZ-OSORIO C, GONZÁLEZ-FÉLIX ML, PEREZ-VELAZQUEZ M: Biological performance of Totoaba macdonaldi in response to dietary protein level. Aquaculture 362-363: 50-54, 2012.

MIRANDA LE, SONSKI AJ: Survival of red drum fingerlings in fresh water: dissolved solids and thermal minima. Proceedings of the Annual Conference of the Southeastern Association of Fish and Wildlife Agencies 39: 228237, 1985.

MYERS JJ, KOHLER CC: Acute responses to salinity for sunshine bass and palmetto bass. N Am J Aquacult 62: $195-$ 202, 2000.

MYLONAS CC, PAVLIDIS M, PAPANDROULAKIS N, ZAISS MM, TSAFARAKIS D, PAPADAKIS IE, VARSAMOS S: Growth performance and osmoregulation in the shi drum (Umbrina cirrosa) adapted to different environmental salinities. Aquaculture 287: 203-210, 2009.

NEILL WH: Environmental requirements of red drum. In: Red Drum Aquaculture. CHAMBERLAIN GW, MIGET RJ, HABY MG (eds), Texas A\&M University Sea Grant College Program, TAMU-SG-90-603, Galveston, TX, USA, 1990, p. 105-108.

OFFICIAL MEXICAN NORM, NOM-062-ZOO-1999: Technical Specifications for the Production, Care, and Use of Laboratory Animals. (in Spanish) Official Journal of the Federation, August 22, 2001.

PARTRIDGE GJ, LYMBERY AJ: Effects of manganese on juvenile mulloway (Argyrosomus japonicus) cultured in water with varying salinity - implications for inland mariculture. Aquaculture 290: 311-316, 2009.

PARTRIDGE GJ, LYMBERY AJ, GEORGE RJ: Finfish mariculture in Inland Australia: a review of potential water sources, species, and production systems. J World Aquacult Soc 39: 291-310, 2008.

PIROZZI I, BOOTH MA, ALLAN GL: The interactive effects of dietary protein and energy on feed intake, growth and protein utilization of juvenile mulloway (Argyrosomus japonicus). Aquacult Nutr 16: 61-71, 2010.

RAJABI H, KHODABANDEH S: Osmoregulation ability in different sizes of Caspian trout (Salmo trutta caspius) parrs, with the same age, following direct transfer from fresh water to the Caspian sea water. J Agric Sci Technol 15: 272-292, 2013.

RESLEY MJ, WEBB KA, HOLT GJ: Growth and survival of juvenile cobia, Rachycentron canadum, at different salinities in a recirculating aquaculture system. Aquaculture 253: 398-407, 2006.

RICKER WE: Computation and interpretation of biological statistics of fish populations. B Fish Res Board Can 191: 1$382,1975$.

ROMÁN-RODRIGUEZ MJ: Sciaenids of the Biosphere Reserve, Upper Gulf of California. (in Spanish) Pesca $y$ Conservación 2: 7-8, 1998. 
ROMÁN-RODRIGUEZ MJ: Population Studies of the Northern Chano Micropogonias megalops and the Gulf corvina Cynoscion othonopterus (Gilbert) (Pisces: Sciaenidae), Species Endemic to the Upper Gulf of California, Mexico. (in Spanish) Informe final SNIB-CONABIO proyecto No. L298, Institute for the Environment and Sustainable Development of the State of Sonora, Mexico D.F., 2000, 154 pp.

ROSALES-LEIJA M, GONZÁLEZ-FÉLIX ML, PEREZ-VELAZQUEZ M, LAWRENCE AL: Shrimp culture in the presence of WSSV during the 2011 cycle in two farms of Sonora, Mexico. In: Aquaculture America 2012. Las Vegas, Nevada, USA. February 28-March 02, 2012, p. 410.

ROWELL K, FLESSA KW, DETTMAN DL, ROMÁN M: The importance of Colorado River flow to nursery habitats of the Gulf corvina (Cynoscion othonopterus). Can J Fish Aquat Sci 62: 2874-2885, 2005.

SAMPAIO LA, BIANCHINI A: Salinity effects on osmoregulation and growth of the euryhaline flounder Paralichthys orbignyanus. J Exp Mar Biol Ecol 269: 187-196, 2002.

SAOUD IP, KREYDIYYEH S, CHALFOUN A, FAKIH M: Influence of salinity on survival, growth, plasma osmolality and gill $\mathrm{Na}^{+}-\mathrm{K}^{+}$-ATPase activity in the rabbitfish Siganus rivulatus. J Exp Mar Biol Ecol 348: 183190, 2007.

SUCHY MD: Effects of Salinity on Growth and Survival of Larval and Juvenile Alligator Gar Atractosteus spatula, and on Plasma Osmolality of Non-teleost Actinoperygiian Fishes. Master of Science Thesis, Nicholls State University, Thibodaux, Lousiana, USA, 2007, 95 pp.

TOMASSO JR, KEMPTON CJ: Effects of salinity on production characteristics of red drum Sciaenops ocellatus. $J$ Appl Aquacult 10: 67-71, 2000.

TSUI WC, CHEN JC, CHENG SY: The effects of a sudden salinity change on cortisol, glucose, lactate, and osmolality levels in grouper Epinephelus malabaricus. Fish Physiol Biochem 38: 1323-1329, 2012.

TURANO MJ, DAVIS DA, ARNOLD DR: Optimization of growout diets for red drum, Sciaenops ocellatus. Aquacult Nutr 8: 95-101, 2002.

VARSAMOS S, NEBEL C, CHARMANTIER G: Ontogeny of osmoregulation in postembryonic fish: a review. Comp Biochem Physiol, Part A 141: 401-429, 2005.

WANG Y, GUO JL, BUREAU DP: Effects of dietary protein and energy levels on growth, feed utilization and body composition of cuneate drum (Nibea michthioides). Aquaculture 252: 421-428, 2006.

WILSON JM, LAURENT P: Fish gill morphology: inside out. $J$ Exp Zool 293: 192-213, 2002.

WURTS WA, STICKNEY RR: Growth rates of juvenile red drum Sciaenops ocellatus reared on commercial salmon feed in fresh and salt water. J World Aquacult Soc 24: 422-424, 1993. 